Hal. 10-16

\title{
Implementasi Transparansi Publik Di Biro Umum Humas Dan Protokol Pemerintah Daerah Daerah Istimewa Yogyakarta
}

\author{
Sandy Tirta Prasadana (1), Sugiyanto (2)
}

(1) Sekolah Tinggi Pembangunan Masyarakat Desa “APMD” Yogyakarta

(2) Sekolah Tinggi Pembangunan Masyarakat Desa "APMD” Yogyakarta

Email Korespondensi: sandy.tirta@gmail.com ; probosugiyanto@gmail.com

\begin{abstract}
Abstrak: Era reformasi membawa perubahan pada posisi tawar masyarakat dihadapan negara. Dulu masyarakat merupakan obyek pembangunan dan kini menjadi subyek pembangunan. Perubahan posisi tersebut mengilhami lahirnya istilah transparansi publik. Di era keterbukaan informasi publik seperti saat ini pertanggungjawaban menjadi point penting yang dinginkan oleh setiap elemen masyarakat. Tuntutan masyarakat kepada pemerintah untuk terbuka menjadi tuntutan wajib yang harus diikuti dan bukan hanya gertak sambal belaka. Penulis ingin melihat media komunikasi yang dipergunakan oleh Biro Umum, Humas dan Protokol Pemerintah Daerah Daerah Istimewa Yogyakarta dalam rangka mewujudkan transparansi publik. Metode penelitian yang digunakan adalah kualitatif dengan pendekatan eksploratif. Penelitian eksplorasi hanya sebatas mengeksplorasi pertanyaan penelitian dan tidak bermaksud untuk menawarkan solusi akhir dan konklusif untuk masalah yang ada. Hasil penelitian mengemukakan bahwa pertama, transparansi publik yang dilaksanakan oleh Biro Umum, Humas dan Protokol Pemerintah Daerah Daerah Istimewa Yogyakarta dilakukan melalui media sosial yang dikelola biro. Kedua, media informasi yang digunakan meliputi pertama, Sengguh. Kedua, Sisminkada, Ketiga, Instagram. Keempat, You Tube. Kelima, Website biro UHP. Keenam, website Pemda DIY. Ketujuh, Facebook. Kedelapan, Twitter.
\end{abstract}

Kata kunci; Implementasi; Transparansi Publik; Pemda.

\begin{abstract}
The era of reform brought changes to the bargaining position of society before the state. In the past, society was the object of development and is now the subject of development. The change in position inspired the birth of the term public transparency. In the era of public information disclosure as it is today accountability becomes an important point that is cooled by every element of society. The public's demand to the government to be open becomes a mandatory demand that must be followed and not just a bluff. The author wants to see the communication media used by the General Bureau, Public Relations and Protocol of the Yogyakarta Special Regional Government in order to realize public transparency. The research method used is qualitative with an exploratory approach. The authors want to examine the natural condition of objects that researchers are key instruments in data collection. The problems studied have never been pared down by anyone else. The results of the study stated that first, public transparency carried out by the General Bureau, Public Relations and Protocol of the Yogyakarta Special Regional Government was carried out through social media managed by the bureau. Second, the information media used includes first, Sengguh. Second, Sisminkada, Third, Instagram. Fourth, You Tube. Fifth, the UHP bureau website. Sixth, the DIY local government website. Seventh, Facebook. Eighth, Twitter.
\end{abstract}

Keywords: Implementation; Public Transparency; Local Government.

Informasi Artikel: Disubmit: 2021-10-26; Direvisi 2021-11-26; Disetujui: 2022-01-12

\section{PENDAHULUAN}

Indonesia menganut sistem otonomi daerah dimana pemerintah pusat memberikan wewenang kepada daerah untuk mengurus kepentingan daerahnya masing-masing, akuntabilitas daerah merupakan suatu keharusan bagi organisasi pemerintah daerah. Akuntabilitas dapat menjembatani antara kepentingan legislatif, eksekutif, dan masyarakatnya. Membangun struktur organisasi pemerintah daerah harus disertakan pengukuran standar kinerja yang tentunya sesuai dengan 
karakteristik daerah masing-masing. Pengukuran kinerja merupakan suatu keharusan antara pemerintah daerah, DPRD, dan masyarakat di dalam menyatukan persepsi atau pemahaman mengenai good governance di daerah (Sartika\& Arieyasmieta, 2021).

Mewujudkan akuntabilitas kinerja pemerintah, pemerintah mengaturnya dengan Perpres No 29 Tahun 2014 tentang Sistem Akuntabilitas Kinerja Instansi Pemerintah atau sering dikenal dengan SAKIP. Organisasi pemerintah (Dinas) pada sektor publik merupakan unsur pelaksana yang dipimpin oleh kepala dinas yang berada di bawah dan bertanggungjawab kepada Bupati/Walikota/Gubernur melalui Sekretaris Daerah. Dinas pada tingkat Kab/Kota/Provinsi merupakan instansi yang menerima dan menggunakan anggaran untuk menjalankan tugas pokok dan fungsinya, oleh karena itu mempunyai kewajiban untuk membuat akuntabilitas kinerja sebagai pertanggungjawaban atas penerimaan serta penggunaan anggaran baik APBD maupun APBN. Akuntabilitas pemerintah daerah terhadap pemerintah yang lebih tinggi timbul karena pemerintah yang lebih tinggi memiliki otoritas untuk mengawasi pemerintah yang lebih rendah. Di Indonesia pemerintah pusat mengalokasikan dana yang berasal dari APBN untuk penyelenggaraan desentralisasi pemerintahan. Laporan pertanggungjawaban tehadap pengelolaan dana dilaporkan secara berjenjang dari Kab/Kota ke Provinsi dan kemudian ke pusat. Menurut Insruksi Presiden No 7 Tahun 1999 tentang Akuntabilitas Kinerja Instansi Pemerintah terdapat sasaran akuntabilitas instansi pemerintah daerah sebagai sub sistem dari sistem akuntabilitas kinerja instansi pemerintah yaitu:

a) Menjadikan instansi pemerintah yang akuntabel sehingga dapat beroperasi secara efisien, efektif dan responsive terhadap aspirasi masyarakat dan lingkungannya.

b) Terwujudnya transparansi instansi pemerintah.

c) Terwujudnya partisipasi masyarakat dalam pelaksanaan pembangunan nasional.

d) Terpeliharanya keperayaan masyarakat kepada pemerintah.

Reformasi merupakan proses pembentukan atau perubahan sistem yang telah ada pada suatu masa diganti dengan yang baru, sehingga era reformasi membawa perubahan pada posisi tawar masyarakat dihadapan negara. Salah satu hasil reformasi Indonesia adalah dulu masyarakat merupakan obyek pembangunan terjadi perubahan yang baru masyarakat menjadi subyek pembangunan. Perubahan posisi tersebut mengilhami lahirnya Peraturan Pemerintah Nomor 101 Tahun 2000 tentang Good Governance (GG). Ruh dari GG merupakan suatu pemerintahan yang dapat mengembangkan dan menetapkan prinsip-prinsip profesionalitas, akuntabilitas, transparansi, pelayanan prima, demokrasi, efisiensi, efektivitas, supremasi hukum dan dapat diterima oleh seluruh masyarakat. Atas dasar itu istilah transparansi publik merupakan turunan dari GG. Di era keterbukaan informasi publik seperti saat ini transparansi dan pertanggungjawaban menjadi point penting yang dinginkan oleh setiap elemen masyarakat.

Berdasarkan pengamatan awal di lapangan, peneliti mengambil celah beberapa permasalahan dalam penyelenggaraan pemerintahan pada Biro Umum Humas dan Protokol Pemda DIY. Untuk mewujudkan visi dan misi instansi maka diperlukan ASN yang berkompeten. Melihat kenyataan di lapangan, ASN pada Biro Umum Humas dan Protokol banyak yang sudah berusia mendekati masa pensiun dimana semangat dalam bekerja semakin menurun ditandai dengan adanya beberapa pegawai yang melakukan titip absen kepada rekannya serta terjadi tumpang tindih ketugasan pegawai, penguasaan akan teknologi sangat rendah, dan pengadaan barang dan jasa yang belum efektif dan efisien. Lalu yang menjadi pertanyaan adalah sejauh mana Biro Umum Humas dan Protokol Pemda DIY berkontribusi dalam SAKIP Pemda DIY yang berkategori AA alias yang terbaik di Indonesia. Dengan kelemahan mendasar apakah akuntabilitas di Biro Umum Humas dan Protokol Pemda DIY berjalan sepenuhnya sesuai yang diharapkan yaitu akuntabel dan benar-benar kredibel?

Tuntutan masyarakat kepada pemerintah untuk terbuka menjadi tuntutan wajib yang harus diikuti dan bukan hanya menjadi slogan. Situasi reformasi akhirnya menjadi perhatian semua organisasi pemerintah diseluruh Indoensia termasuk pemerintah daerah. Pemerintah Daerah Daerah Istimewa Yogyakarta (DIY), dalam upaya mewujudkan GG Pemerintah DIY bekerja keras sehingga mendapat prestasi provinsi yang meraih nilai AA dari KemenPAN-RB untuk SAKIP/Sistem Akuntabilitas Kinerja Instansi Pemerintah pada tahun 2020. Predikat ini merupakan penilaian tertinggi nasional yang didapatkan suatu provinsi. Pemerintah Daerah Daerah Istimewa Yogyakarta meraih nilai 90,19 dan menjadi yang terbaik dari 539 pemerintah daerah Provinsi, Kabupaten dan 
Kota di seluruh Indonesia. Nilai tinggi yang didapatkan tidak terlepas dari transparansi publik yang dibangun dan dikembangkan oleh Pemerintah Daerah Daerah Istimewa Yogyakarta.

Menurut Sugiyanto (2020:171), Pemerintah Daerah DIY dalam mencapai prestasi nilai AA diduga semua organ pemerintah telah membatasi dan mengatur perilaku pribadi dalam sistem sehingga pertarungan kebebasan pribadi dikendalikan melalui tanggungjawab kolektif sehingga antar aktor tidak ada hidden action dan hidden information. Kondisi ini menunjukan bahwa Biro Umum, Humas dan Protokol Pemerintah Daerah Daerah Istimewa Yogyakarta sudah menyadari pentingnya informasi yang diberikan masyarakat benar, jelas, terbuka, dan jujur sesuai dengan fakta dan konsep informasi modern, bahwa informasi harus tersebar luas baik internal dan eksternal. Situasi ini sebagai bukti bahwa organ di Biro Umum, Humas dan Protokol Pemerintah Daerah Daerah Istimewa Yogyakarta: a) patuh pada aturan eksternal kususnya kode etik humas., b) literasi pegawai cukup tinggi sehingga mampu adaptasi cepat terhadap knowledge society menuju e-government (Nugraha, 2018).

Pertanyaan penelitian dalam paper ini adalah pertama, bagaimana respon masyarakat terhadap materi dan media publikasi yang dipergunakan oleh Biro Umum, Humas dan Protokol Pemerintah Daerah Daerah Istimewa Yogyakarta. Kedua, jenis media publikasi yang digunakan Biro Umum, Humas dan Protokol dalam mensosialisasikan kebijakan pemerintah daerah. Tujuan penelitian untuk mendeskripsikan transparansi publik Biro Umum, Humas dan Protokol Pemerintah Daerah Daerah Istimewa Yogyakarta. Atas dasar hal di atas paper ini akan mengeksplorasi media publikasi yang digunakan Biro Umum, Humas dan Protokol dalam mensosialisasikan kebijakan pemerintah daerah, dan mendiskripasikan bagaimana respon masyarakat terhadap materi dan media publikasi yang dipergunakan oleh Biro Umum, Humas dan Protokol Pemerintah Daerah Daerah Istimewa Yogyakarta. Hal ini penting dipublikasikan dengan harapan sistem kerja Biro Umum, Humas dan Protokol Pemerintah Daerah Daerah Istimewa Yogyakarta dapat diadopsi Pemerintah Daerah lain dan mendapat respon publik baik dari pemerintah daerah maupun dari kalangaan akademisi, peneliti dan pemerhati dibidang humas dan protokol Pemerintah Daerah.

\section{METODE PENELITIAN}

Penelitian tentang transparansi publik di Biro Umum, Humas dan Protokol Pemerintah Daerah Daerah Istimewa Yogyakarta dilakukan dengan pendekatan kualitatif eksplorasi. Menurut (Mudjiyanto. B, 2018), penelitian eksplorasi hanya sebatas mengeksplorasi pertanyaan penelitian dan tidak bermaksud untuk menawarkan solusi akhir dan konklusif untuk masalah yang ada, desain penelitian eksplorasi tidak bertujuan untuk memberikan jawaban final dan konklusif untuk pertanyaan penelitian. Subyek penelitian ditentukan dengan menggunakan metode purporsive sampling terhadap pejabat teras di Biro Umum, Humas dan Protokol Pemerintah Daerah Daerah Istimewa Yogyakarta. Data dikumpulkan dengan menggunakan metode wawancara mendalam, observasi dan studi pustaka/data. Ketiga sumber data dintegrasi satu sama lain dalam sebuah analisis. Validasi data dilakukan uji derajat kepercayaan (credibility) melalui triangulasi sumber, waktu, teknik, teori dan hasil. Dari credibility validasi hasil dilanjutkan dengan uji transferability, dependability dan conformability (Sugiyanto,eat, al. 2019).

\section{HASIL DAN PEMBAHASAN}

Hasil dan pembahasan implementasi transparansi publik di Biro Umum Humas dan Protokol Pemerintah Daerah DIY dikelompokan menjadi dua sesuai dengan pertanyaan penelitian diawali dengan temuan data sebagai berikut:

\section{Data hasil penelitian}

Masyarakat puas dengan materi dan informasi yang disajikan ke dalam delapan media publikasi kebijakan yang dikelola oleh Biro Umum, Humas dan Protokol. Dalam rangka memberikan feedback kepada masyarakat, Biro Umum, Humas dan Protokol Pemerintah Daerah Daerah Istimewa Yogyakarta menggelar survei internal untuk mengetahui sejauhmana respon masyarakat terhadap informasi peneliti menganalisis hasil survei Biro Umum, Humas dan Protokol disajikan pada tabel 1

\section{(cc) BY-SA}

This work is licensed under a

Creative Commons Attribution-ShareAlike 4.0 International License. 
sebagai berikut: Respon masyarakat terhadap materi dan media publikasi yang dipergunakan oleh Biro Umum, Humas dan Protokol Pemerintah Daerah DIY

Tabel 1. Nilai Kepuasan Masyarakat terhadap Informasi Pemerintah Daerah

\begin{tabular}{|c|c|c|}
\hline No. & Bulan & Nilai Kepuasan Layanan \\
\hline 1. & Januari - Maret & 92,75 \\
\hline 2. & Januari - Juni & 93,92 \\
\hline 3. & Januari - September & 93,75 \\
\hline 4. & Januari - Desember & 95,54 \\
\hline
\end{tabular}

Sumber: Biro Umum, Humas dan Protokol DIY, 2020

Tabel 1 diatas menunjukkan bahwa masyarakat merasa puas dengan informasi yang dipaparkan melalui media publikasikan kebijakan yang dikelola Biro Umum, Humas dan Protokol Pemerintah Daerah, Daerah Istimewa Yogyakarta. Penjelasan dibidang penyiapan informasi kebijakan pemda akan disampaikan oleh bapak AF selaku Kasubbag Penyiapan Informasi Kebijakan Pemda. Uraian selengkapnya adalah sebagai berikut:

"Sub bagian penyiapan informasi kebijakan pemda adalah unit yang bekerja untuk menyiapkan analisis berita yang akan diupload ke media sosial dan website yang dikelola oleh kami. contoh analisis berita tentang kebijakan DIY menjadi wilayah yang bebas pungli yang diupload di media Youtube. Kedua, melakukan analisis berita yang berhubungan dengan pemerintah daerah yang selama ini beredar didunia maya. Dari analisis tersebut kita bisa tahu apakah berita ini perlu ditanggapi lebih lanjut atau tidak oleh para stakeholder yang berkompeten untuk menjelaskan duduk permasalahan tersebut. Tugas ini diemban berdasarkan Pergub Nomor 53 tahun 2018 pasal 106 ayat 2”. (wawancara 4 Juli, 2021)

Secara garis besar menjelaskan bahwa substansi berita menjadi kunci pokok bagi pemerintah daerah untuk memberikan feedback kepada informasi yang menjadi pembicaraan hangat ditengahtengah masyarakat Daerah Istimewa Yogyakarta. Demi mempermudah pembaca memahami pernyataan diatas, maka penulis akan memberikan contoh salah satu artikel berita yang diupload di media Youtube milik Pemerintah Daerah Istimewa Yogyakarta.

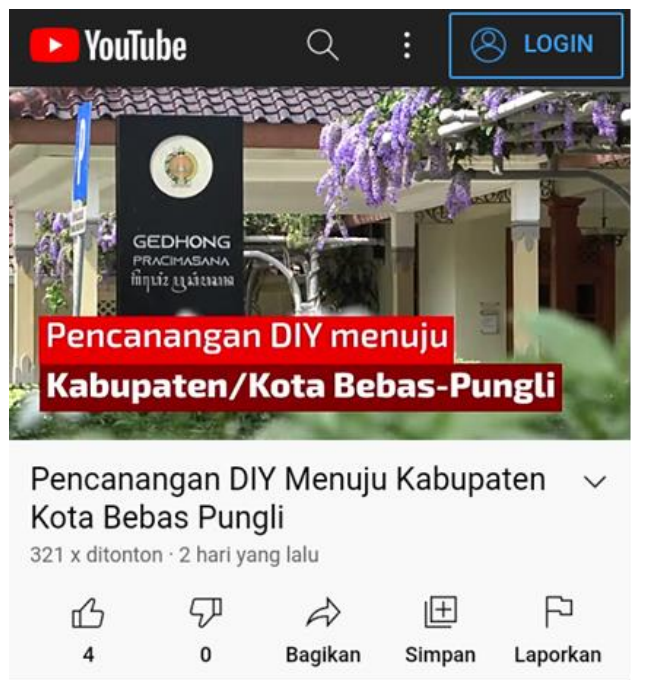

Gambar 1. Contoh Berita Youtube Pemda DIY

Sumber: Biro Umum, Humas dan Protokol DIY, 2021 
Pada gambar 1. menampilkan contoh berita tentang pencanangan Daerah Istimewa Yogyakarta menuju kabupaten/kota yang bebas pungli. Sebelum berita ini dimasukkan ke Youtube, para staf yang bekerja di unit penyiapan informasi kebijakan pemda menggali informasi yang lebih jauh tentang kebijakan Daerah Istimewa Yogyakarta tentang pemberantasan pungli melalui regulasi dalam bentuk perda maupun regulasi lain. Informasi yang didapatkan akan diolah sedemikian rupa sesuai dengan kaidah jurnalistik dan standar yang telah ditetapkan oleh unit penyiapan informasi kebijakan pemda. Setelah memenuhi kriteria yang telah ditentukan, berita dimasukkan ke media Youtube milik Pemerintah Daerah Istimewa Yogyakarta.

2. Jenis media pubilikasi yang digunakan Biro Umum, Humas dan Protokol dalam mensosialisasikan kebijakan Pemerintah Daerah DIY.

Temuan data berupa media publikasi yang dipergunakan oleh Biro Umum, Humas dan Protokol Pemerintah Daerah Daerah Istimewa Yogyakarta dalam mensosialisasikan kebijakan kepada masyarakat, disajikan dalam tiga bagian yaitu:

a) aplikasi internal milik Pemerintah Daerah Daerah Istimewa Yogyakarta yang terdiri dari: 1) sistem evaluasi pertanggungjawaban, sistem ini merupakan kepanjangan dari sistem evaluasi pertanggungjawaban pembangunan daerah. Didalam aplikasi ini pihak-pihak yang berkepentingan bisa mengakses informasi tentang Rencana Operasional Pelaksanaan Kegiatan (ROPK), anggaran kas, monitoring dan evaluasi capaian kinerja bulanan, triwulan, semesteran dan tahunan seluruh Organisasi Perangkat Daerah. Aplikasi ini dapat diakses melalui website https://sengguh.jogjaprov.go.id. Sengguh merupakan salah satu wujud kongkret penerapan good governance dilingkungan Pemerintah Daerah terutama dalam memantau progress kinerja dan pengelolaan keuangan daerah secara periodik. 2) Sisminkada yang merupakan singkatan dari Sistem Administrasi Perkantoran Daerah. Didalam sistem aplikasi ini masyarakat bisa melihat alur kepengurusan surat, mulai dari surat masuk atau surat keluar, pendistribusian sampai dengan penyimpanan dan tata naskah dinas.

b) Media sosial milik Pemerintah Daerah Daerah Istimewa Yogyakarta yang terdiri dari: 1) Instagram, 2) You Tube, 3) facebook dan 4) Twitter. Keempat media sosial diatas secara umum mempublikasikan agenda Gubernur Daerah Istimewa Yogyakarta.

c) Website Pemerintah Daerah Istimewa Yogyakarta yang berupa: a) website Biro Umum, Humas dan Protokol, b) website Pemerintah Daerah Daerah Istimewa Yogyakarta. Pelaksanaan good governance dilingkungan Pemerintah Daerah Daerah Istimewa Yogyakarta dilakukan melalui penyediaan website sebagai media alternatif bagi masyarakat yang ingin memantau perkembangan kinerja yang dilakukan oleh seluruh Organisasi Perangkat Daerah.

\section{Tanggapan masyarakat}

Berdasarkan tabel 1 di atas perihal survei internal yang dilaksanakan pada bulan Januari sampai dengan Desember 2020 dengan cara penghitungan akumulasi respon pembaca terhadap informasi yang ditayangkan di laman resmi Pemda DIY. Total terdapat 4.151 responden yang memberikan tanggapan terhadap survei tersebut. 95,54\% diantaranya merasa puas atas kualitas layanan informasi yang disajikan oleh Pemerintah Daerah Istimewa Yogyakarta melalui Biro Umum, Humas dan Protokol khususnya unit Subbagian Publikasi, Dokumentasi dan Media Massa yang mengelola seluruh isi/konten yang dimuat di media sosial dan website milik Pemerintah Daerah Daerah Istimewa Yogyakarta.

Hasil survei di atas relevan dengan pertanyaan penelitian yaitu pertama, jenis media publikasi yang digunakan Biro Umum, Humas dan Protokol dalam mensosialisasikan kebijakan pemerintah daerah. Kedua, bagaimana respon masyarakat terhadap materi dan media publikasi yang dipergunakan oleh Biro Umum, Humas dan Protokol Pemerintah Daerah Daerah Istimewa Yogyakarta.

Jurnal ini ditulis berdasarkan hasil penelaah penulis terhadap jurnal ilmiah yang terbit pada edisi sebelumnya. Jurnal terdahulu yaitu pertama, jurnal yang berjudul transparansi dan akuntabilitas dalam pelayanan publik. Jurnal tersebut memaparkan bahwa syarat transparansi dan akuntabilitas belum dipenuhi oleh pelayanan publik (Karjuni Dt Maani : 2009). Hasil penelitian diatas menggambarkan realita dilapangan bahwa cita-cita reformasi birokrasi belum bisa terwujud. Kedua, 
jurnal yang berjudul transparansi dan akuntabilitas dalam pelayanan publik. Studi tentang akuntabilitas dan transparansi pelayanan pada izin usaha di Dinas Perdagangan Kota Surabaya. Jurnal tersebut memaparkan bahwa pelayanan perizinan yang diberikan oleh Dinas Perdagangan belum mampu memberikan informasi secara terbuka kepada masyarakat mengenai persyaratan, waktu, biaya, cara pelayanan, hak dan kewajiban penyelenggara (Fatimah Malahayati Windari Irom Putri : 2017). Dari hasil riset diatas menunjukkan bahwa reformasi internal Organisasi Perangkat Daerah belum berjalan dengan maksimal.

Ketiga, jurnal yang berjudul analisis transparansi dalam penyelenggaraan pelayanan publik Di kantor Dinas Penanaman Modal dan Pelayanan Satu Pintu Kabupaten Bone. Jurnal tersebut memaparkan bahwa Kantor Dinas Penanaman Modal dan Pelayanan Satu Pintu Kabupaten Bone sudah terimplementasikan sesuai dengan apa yang diharapkan oleh masyarakat dari segi prosedur pelayanan, persyaratan teknis, administrasi pelayanan, rincian biaya pelayanan, lokasi pelayanan, janji pelayanan, standar pelayanan dan informasi pelayanan (Marjana Fahri: 2018). Riset di Kabupaten Bone menunjukkan bahwa ada perkembangan yang cukup signifikan dalam reformasi kelembagaan khususnya di tingkatan Organisasi Perangkat Daerah.

Jurnal yang ditulis oleh peneliti memiliki topik berbeda dengan ketiga jurnal diatas. jurnal yang ditulis membahas tentang transparansi publik dari sudut pandang media komunikasi dan penelitian ini dilakukan di Biro Umum, Humas dan Protokol Pemerintah Daerah Daerah Istimewa Yogyakarta. Konsep yang mendukung adanya transparansi publik dikemukakan oleh Agus Dwiyanto (2006:80), yang memaparkan bahwa transparansi sebagai penyediaan informasi tentang pemerintahan bagi publik dan dijamin kemudahan di dalam memperoleh informasi yang akurat dan memadai. Pemaparan diatas menekankan pentingnya bahan informasi sebagai gambaran umum pengelolaan barang milik pemerintah yang harus diberikan kepada masyarakat secara periodik sebagai bentuk transparansi dan akuntabilitas kepada masyarakat.

Pakar lain yaitu Mardiasmo (2004:30), mengemukakan bahwa transparansi adalah keterbukaan pemerintah dalam memberikan informasi terkait dengan aktivitas pengelolaan sumber daya publik kepada pihak-pihak yang membutuhkan informasi. Konsep yang dikemukakan oleh Mardiasmo menekankan kewajiban pemerintah pusat dan daerah dalam membuka dan meningkatkan aksesbilitas informasi penggunaan aset negara.

Dua konsep diatas sangat berbeda dengan konsep yang dikemukakan Budiman (1991), yang memaparkan bahwa orde baru mengusung model birokrasi terpusat atau yang sering di kenal dengan istilah otoriter birokratik yang menekankan pertama, penggunaan birokrasi dalam mencapai tujuan. Kedua, mencegah partisipasi masyarakat dan ketiga, menyelenggarakan kegiatan ekonomi dan politik secara top down. Penyelenggaraan pelayanan publik yang tertutup di masa lalu sangat rawan penyimpangan yang dilakukan oleh elit-elit birokrasi. Demi tujuan memperkaya diri sendiri maupun orang lain. Atas dasar inilah kemudian lahir konsep transparansi birokrasi sebagai anti tesis otoriter birokratik yang mendominasi Indonesia selama 32 tahun lamanya.

\section{KESIMPULAN}

Masyarakat yang mengakses media publikasi kebijakan merasa puas dengan materi yang disajikan. Informasi yang dipaparkan tidak mengandung unsur hidden information dan hidden action. Kebijakan-kebijakan strategis dan berkaitan langsung dengan kebutuhan masyarakat luas dipublikasikan, agar masyarakat bisa memantau progress pembangunan. Kualitas ini tergambar jelas pada media publikasi kebijakan dan kegiatan pimpinan yang dikelola oleh Biro Umum, Humas dan Protokol Pemerintah Daerah Daerah Istimewa Yogyakarta beraneka ragam dan dipandang mampu menyajikan dan menyampaikan informasi yang up to date.

\section{REFERENSI}

Agus Dwiyanto. 2008. Mewujudkan Good Governance Melalui Pelayanan Publik, Cet. III. Yogyakarta: Gadjah Mada University Press.

Budiman, Arief. 1991. Negara dan Pembangunan Studi tentang Indonesia dan Korea Selatan, Cet. I. Salatiga : Yayasan Padi dan Kapas. 
Dt Maani, Karjuni. 2009. Transparansi dan Akuntabilitas dalam Pelayanan Publik. Demokrasi Vol. 8 No. 1 Th. 2009:47-48.

Fahri, Marjani. 2018. Analisis Transparansi dalam Penyelenggaraan Pelayanan Publik Di kantor Dinas Penanaman Modal dan Pelayanan Satu Pintu Kabupaten Bone. Jurnal Al-Adalah Vol. 3, Nomor I, Januari 2018:29-44.

Mardiasmo. 2002. Otonomi dan Manajemen Keuangan Daerah. Yogyakarta : Andi

Moleong, Lexy J. 2015. Metode Penelitian Kualitatif. Bandung: Remaja Rosdakarya.

Nasution. 2014. Metode Research: Penelitian Ilmiah. Jakarta : Bumi Aksara.

Nugraha, J.T., 2018. E-Government Dan Pelayanan public : Studi teentang Elemen Sukses pengembangan E-Government Di Pemerintah kabupaten Sleman. Jurnal Komunikasi dan Kajian Media Vol 2. No. 1. Edisi April 2018: 32-42.

Sartika, D., \& Arieyasmieta, W. L. (2021). Sistem Manajemen Anti Penyuapan Iso 37001: 2016 Dan Reformasi Birokrasi (Studi Kasus Pada Pusat Pelatihan Dan Pengembangan Dan Kajian Desentralisasi Dan Otonomi Daerah). Jurnal Standardisasi, 23(1), 13-22.

Sugiyanto. Hartono,A., Khuluq, L., and Tjahjono HK. 2019. Value of Organization versus Theory Organization Case Study In Mardi wuto and Hamba Social Walfare Institution Special Region Of Yogyakarta. International Journal of Recent Scientific Research. 10. 09 (D) page 34759-34767. IJRSFP (USA).

Sugiyanto. 2020. Tipologi Governance Lembaga Kesejahteraan Sosial. CV. Magna Raharja Tama, Yogyakarta.

Sugiyono. 2015. Metode Penelitian Kuantitatif, Kualitatif dan R\&D.Bandung: Alfabeta.

Windari Irom Putri dan Fatimah Malahayati. 2018. Transparansi dan Akuntabilitas dalam Pelayanan Publik. Studi tentang Akuntabilitas dan Transparansi Pelayanan pada Izin Usaha di Dinas Perdagangan Kota Surabaya. Fakultas Ilmu Sosial dan Ilmu Politik, Universitas Airlangga, Surabaya. 